'Departiment of Animal Production, Faculty of Agriculture, Ain Shams University, Shoubra Al-kheima, Cairo, Egypt and ${ }^{2}$ Tanta University, Egypt.

KARIMA A. SHAHIN ${ }^{1}$, AHMED R. SHEMEIS ${ }^{1}$, OMAR Y. ABDALLAH $^{1}$ and KAMAL SALEH ${ }^{2}$

\title{
Selection index alternatives for increased marketing body weight with minimum concomitant reduction in body bone percentage- recourse to tissue dissection on Japanese quail
}

\begin{abstract}
Summary
Live body weight, shank length, keel length and carcass dissection data taken at 6 weeks of age were available on 103 quails from 33 sires. In a principal factor analysis, the first varimax rotated factor explaining $46.1 \%$ of the total variation, revealed that body weight had negative loading and all bone percentages positive. The implied contrast was confirmed by the finding that body weight $\left(\mathrm{h}^{2}=0.61\right)$ was genetically correlated negatively with weight of total bone relative to body weight $(-0.23)$ and to carcass weight $(-0.58)$. Noticeably, shank length $(\mathrm{SL})$ had large positive genetic correlation with body weight $(0.90)$ and practically independent relationship with body bone percentage $(-0.04)$.

Selection indexes for meat production capacity were constructed. The breeding goal was defined as body weight (BW) and body bone percentage (BBP). The descending order of the unrestricted indexes with respect to the correlation between the index and genetic worth was: the full index utilising body weight, shank length and keel length $(0.95)$, indexes based on body weight and one length measurement $(0.86)$, body weight alone $(0.78)$. The accuracy was reduced by $17-35 \%$ upon restraining changes in BBP to zero. This study indicated that an index of considerable accuracy and remarkable usefulness would be $\mathrm{I}_{3}=4.56 \mathrm{BW}+244.87 \mathrm{SL}$. Use of this index should result in developing birds with higher body weight and more advantageous carcass attributes than selecting for body weight alone $\left(\mathrm{I}_{4}\right)$ or on the restricted full index $\left(\mathrm{I}_{1(\mathrm{BBP})}\right)$. Such three indexes were most efficient in limiting reduction in $\mathrm{BBP}$.
\end{abstract}

Key Words: selection index, body weight, bone weight, slaughter traits, Japanese quail

\section{Zusammenfassung}

Titel der Arbeit: Selektionsindizes mit dem Ziel der Erhöhung des Kðrpergewichtes bei gleichzeitiger Reduzierung des Knochenanteiles bei Wachteln

An 103 sechs Wochen alten Wachteln aus 33 Hähnen wurden mehrere Lebendgewichte und Lebendmaße sowie Schlachtgewichte und Schlachtmaße ermittelt. Diese Daten konnten für die Schătzung phänotypischer und genetischer Parameter genutzt werden. Relativ hohe $\mathrm{h}^{2}$-Schätzwerte wurden fur Körpergewicht, Schlachtgewicht und Knochenanteil geschätzt. Die phänotypischen und genetischen Korrelationen zwischen Körpergewicht und Knochengewicht sowie -anteil waren negativ. Hohe genetische Korrelationen wurden für Rőhrbeinlănge und Körpergewicht geschätzt. Die Daten wurden für die Konstruktion von Selektionsindizes genutzt. Einzelne Indexvarianten mit und ohne Restriktion bei unterschiedlicher Selektionsintensităt werden vorgestellt und ihre Effizienz unter dem Aspekt der Erhø̆hung von Körpergewicht bei Reduzierung des Knochenanteiles diskutiert.

Schlüsselwörter: Selektionsindex, Körpergewicht, Knochengewicht, Schlachtmerkmale, Wachtel

\section{Introduction}

In Egypt, the primary interest of quail breeders seems to be concentrated on the improvement of 6-week marketing weight and dressing percentage (KOSBA et al., 1992; HASSAN et al., 1992). Practically no attention might possibly be paid to the grade of the marketed birds. However, it is well established (especially in turkeys and 
broilers) that selection for increased body weight is accompanied by biologically incompatible reduction in relative weight of skeleton (the leg bones in particular) which would at the producer level, magnify the severity of eventual leg problems (MERCER and HILL, 1984; NESTOR et al., 1987; LILBURN, 1994). To the authors' knowledge, no selection indexes are available to select for increased body weight while limiting reduction in body bone percentage. The development of such indexes are discussed in this paper with special reference to expected genetic changes on body weight, body bone percentage and the related meat production attributes.

\section{Material and Methods}

Source of data. Fifty-one male and fifty-two female Japanese quail (Coturnix Coturnix Japonica), progeny of thirty-three sires were used in this study. Quail chicks were produced and reared at the poultry farm of the Faculty of Agriculture, Tanta University, Egypt. They were fed a growing diet containing $24 \%$ protein and a metabolizable energy of $2931 \mathrm{Kcal} / \mathrm{kg}$ from hatching to six weeks of age. Feeds and water were provided ad libitum and conventional brooding and rearing practices were followed.

Traits considered. At six weeks of age, birds were weighed and the lengths of their shanks and keels were measured (KRUEGER et al., 1972) before being slaughtered and their carcasses halfed. The right side of each carcass was frozen (at $-20^{\circ} \mathrm{C}$ ) then transferred to the meat laboratory of the Faculty of Agriculture, Ain Shams University, to be thawed (at $5{ }^{\circ} \mathrm{C}$ ) and jointed into leg (drumstick and thigh), breast and wing (SHAHIN et al., 1990). Twice the weight of the total muscle, total bone and total fat dissected from the side gives respectively, total carcass muscle, fat and bone, the sum of which gives the (dissected) side weight. Twice the latter gives the (dissected) carcass weight.

Statistical analysis.

Rotated factors pattern. The weights of the live body, total offal, the dissected major tissues and the dissected bone from the five cuts were subjected to the principal factor analysis (DARTON, 1980) to define the rotating factor pattern involved in describing the body mass. The model used was as follows:

where:

$$
\mathbf{X}=\wedge \mathbf{F}+\mathbf{U}
$$

$\mathrm{X}=\mathrm{a} \mathrm{p} \times 1$ vector of observable variables,

$\wedge=\mathrm{a} \mathrm{p} \mathrm{x} \mathrm{q} \mathrm{matrix} \mathrm{of} \mathrm{factor} \mathrm{loadings} \mathrm{(the} \mathrm{pattern} \mathrm{matrix),}$

$\mathrm{F}=\mathrm{a} \mathrm{q} \times 1$ vector of factors (non-observable) and,

$\mathrm{U}=\mathrm{a} \mathrm{p} \times 1$ vector of specific 'unique' factors.

Parameters estimation. The analysis related to parameter estimation used data on the length of shank and keel, the weight of live body and carcass and the percentage of total muscle, total bone, leg bone and breast bone. The genetic and phenotypic parameters were estimated from the sire components of variance and covariance by the least squares and maximum likelihood program (HARVEY, 1990), according to the following mixed model:

where:

$$
\mathbf{Y}_{\mathrm{ijk}}=\mu+\mathbf{F}_{\mathrm{i}}+\mathrm{S}_{\mathrm{j}}+\mathbf{b} \mathbf{X}_{\mathrm{ijk}}+\mathbf{e}_{\mathrm{ijk}}
$$




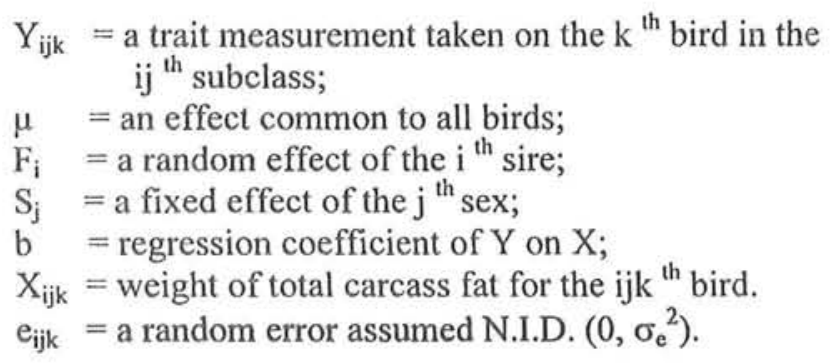

\section{Selection indexes}

Economic values. Net merit was defined as function of marketing body weight. However, as consequence of the improvement of body weight, body bone percentage will decrease to the disadvantage of the producer. Therefore body bone percentage was included in the breeding goal (aggregate genotype). Since the relative economic weights of the two traits are needed and not their absolute L.E. values, the relative economic weights are useful as long as the relationships between the costs do not change. The economic value for body weight relative to that of body bone percentage was assumed to be $10: 1$, considering the average proportion of bone relative to body in the present sample of quails.

Index alternatives. A number of alternatives were constructed (CUNNINGHAM et al., 1970) to improve six-weck body wcight while limiting reduction in bone percentage. The index traits (i.e. sources of information) were body weight, shank length and keel length at six weeks of age.

\section{Results and Discussion}

Rotated factors patterns. The correlations among live body weight and its elements were analysed by the method of principal factor analysis. The results given in Table 1 correspond to the three rotated factors obtained. The first, second and third represent, respectively, $46.1,24.8$ and $10.8 \%$ of the phenotypic variance. On the first factor live weight had negative loading and the relative weight of bone of drumstick, thigh, breast, wing and neck positive. This implies a contrast between the live weight and the percentage of bone in the body. This confirms previous work (c.g. BACON et al., 1986; NESTOR et al., 1987) indicating that as total body weight increased a decline occurs in leg bones and skeleton in general.

Heritabilities. Heritability estimates $\left(h^{2}\right)$ for live and carcass attributes are presented in Table 2.

The body weight at six weeks of age seems to be highly heritable in quails $(0.71$, AHUJA et al., 1983; 0.67, SATO et al., 1986; 0.71, EL-FIKY, 1991; 0.64, SHARAF, 1992; 0.62, SOLIMAN, 1992). The heritability of keel length tends to be generally moderate while being reasonably uniform among poultry species (in chickens: 0.59 , ABDELATIF, 1989; in ducks: 0.50, PINGEL et al., 1969; in turkeys: KRUEGER et al., 1972). For the shank length, however, interspecies differences in $h^{2}$ are obvious (in turkeys: 0.54, KRUEGER et al., 1972; in chickens: 0.31 and 0.33, ABDEL-GAWAD and EL-IBIARY, 1971; 0.58, ABDELATIF, 1989). 
Table 1

Loadings of the three varimax rotated factors of body weight and its elements

\begin{tabular}{lccc}
\hline & \multicolumn{3}{c}{ Factor } \\
\cline { 2 - 3 } & 1 & 2 & 3 \\
\hline Body weight & -0.68 & +0.52 & +0.07 \\
\% Offal & -0.24 & -0.93 & -0.21 \\
\% Total carcass muscle & -0.16 & +0.96 & -0.02 \\
\% Total carcass fat & -0.06 & +0.11 & +0.99 \\
\% Drumstick bone & +0.89 & -0.07 & -0.08 \\
\% Thigh bone & +0.90 & -0.01 & -0.01 \\
\% breast bone & +0.67 & +0.33 & -0.13 \\
\% Wing bone & +0.91 & -0.03 & +0.01 \\
\% Neck bone & +0.83 & +0.01 & +0.06 \\
\% Variance & & & 10.8 \\
\hline
\end{tabular}

Table 2

Means $(\vec{x})$, phenotypic standard deviations $\left(\sigma_{\mathrm{p}}\right)$ and heritabilities $\left(\mathrm{h}^{2}\right)$ for live and slaughter traits

\begin{tabular}{lccc} 
& $\bar{x}$ & $\sigma_{\mathrm{p}}$ & $\mathrm{h}^{2}$ \\
\hline Live traits & & & \\
Body weight, $\mathrm{g}$ & 123.9 & 22.6 & 0.61 \\
Shank length, cm & 3.3 & 0.3 & 0.82 \\
Keel length, cm & 5.9 & 0.5 & 0.37 \\
Slaughter traits & & & \\
Carcass weight, $\mathrm{g}$ & 68.3 & 14.5 & 0.77 \\
(Component wt/body wt), \%: & & & 0.67 \\
Total muscle & 39.71 & 3.51 & 1.00 \\
Total bone & 9.62 & 1.57 & 0.72 \\
$\quad$ Leg bone & 3.79 & 0.71 & 0.93 \\
$\quad$ Breast bone & 1.88 & 0.41 & \\
(Component wt/carcass wt), \%: & & & 0.50 \\
Total muscle & 72.23 & 2.99 & 0.58 \\
Total bone & 17.54 & 2.75 & 0.33 \\
$\quad$ Leg bonc & 6.92 & 1.29 & 0.66 \\
\hline Breast bone & 3.42 & 0.68 & \\
\hline
\end{tabular}

The $h^{2}$-values of 0.77 for carcass weight in the present work is much higher than the estimate of 0.51 and 0.54 obtained in the quails sample investigated by SATO et al. (1982) and SOLIMAN (1992), respectively. Increases in $\mathrm{h}^{2}$-values were noticed (Table 2) with the use of body weight rather than carcass weight as denominator for characterizing the content in total muscle, total bone, leg bone and breast bone. The $\mathrm{h}^{2}$ for $\%$ total bone is higher than for \% total muscle ( 1.00 vs 0.67 and 0.58 vs 0.50 ) and $\mathrm{h}^{2}$-values for \%breast bone exceeds those for \%leg bone $(0.93$ vs 0.72 and 0.66 vs 0.33). Similarly, KAWAHARA and SAITO (1976) on quails found that the heritability estimate of bone weight was higher than that of muscle weight.

Correlations. The genetic and phenotypic associations among the live and slaughter traits are presented in Table 3. Body weight showed a large negative genetic relationship with carcass bone percentage $\left(\mathrm{r}_{\mathrm{G}}=-0.58\right)$ but a low one with body bone percentage $\left(r_{G}=-0.23\right)$. Greater body weight was genetically associated with slightly high keel length (0.29) and negligible change in \% breast bone in body or in carcass. This indicates that the genes that increase body weight would tend to be inherited 
Table 3

Coefficient of phenotypic (above diagonal) and genetic (below diagonal) correlations among live and slaughter traits

\begin{tabular}{|c|c|c|c|c|c|c|c|c|c|c|c|c|}
\hline & \multicolumn{3}{|c|}{ Live traits } & \multirow[b]{2}{*}{$\begin{array}{l}\text { Carcass } \\
\text { weight }\end{array}$} & \multicolumn{4}{|c|}{100 (Component wt/body wt) } & \multicolumn{4}{|c|}{100 (Component wt/carcass wt) } \\
\hline & $\begin{array}{c}\text { Body } \\
\text { weight }\end{array}$ & $\begin{array}{l}\text { Shank } \\
\text { length }\end{array}$ & $\begin{array}{c}\text { Keel } \\
\text { length }\end{array}$ & & $\begin{array}{c}\text { Total } \\
\text { muscle }\end{array}$ & $\begin{array}{l}\text { Total } \\
\text { bone }\end{array}$ & $\begin{array}{l}\text { Leg } \\
\text { bone }\end{array}$ & $\begin{array}{l}\text { Breast } \\
\text { bone }\end{array}$ & $\begin{array}{c}\text { Total } \\
\text { muscle }\end{array}$ & $\begin{array}{l}\text { Total } \\
\text { bone }\end{array}$ & $\begin{array}{l}\text { Leg } \\
\text { bone }\end{array}$ & $\begin{array}{c}\text { Breast } \\
\text { bone }\end{array}$ \\
\hline \multicolumn{13}{|l|}{ Live traits } \\
\hline Body weight, $g$ & & 0.47 & 0.60 & 0.88 & 0.37 & -0.46 & -0.42 & -0.14 & 0.76 & -0.53 & -0.46 & -0.14 \\
\hline Shank length, $\mathrm{cm}$ & 0.90 & & 0.31 & 0.43 & 0.21 & -0.08 & -0.05 & 0.08 & 0.29 & -0.14 & -0.09 & 0.06 \\
\hline Keel length, cm & 0.29 & -0.02 & & 0.67 & 0.43 & -0.02 & -0.03 & 0.12 & 0.42 & -0.18 & -0.15 & 0.03 \\
\hline \multicolumn{13}{|l|}{ Slaughter traits } \\
\hline $\begin{array}{l}\text { Carcass weight, } g \\
\text { (Component wt/body wt), \% : }\end{array}$ & 0.83 & 0.62 & 0.84 & & 0.73 & -0.17 & -0.19 & 0.09 & 0.75 & -0.44 & -0.40 & -0.06 \\
\hline Total muscle & 0.61 & 0.17 & 1.00 & 0.96 & & 0.06 & 0.00 & 0.18 & 0.62 & -0.41 & -0.40 & -0.11 \\
\hline Total bone & -0.23 & -0.04 & 1.00 & 0.26 & 0.50 & & 0.91 & 0.75 & -0.71 & 0.88 & 0.76 & 0.65 \\
\hline Leg bone & -0.03 & 0.12 & 1.00 & 0.37 & 0.45 & 0.94 & & 0.53 & -0.68 & 0.84 & 0.91 & 0.45 \\
\hline Breast bone & 0.07 & 0.41 & 0.97 & 0.40 & 0.40 & 1.00 & 0.96 & & -0.39 & 0.61 & 0.36 & 0.95 \\
\hline \multicolumn{13}{|l|}{ (Component wt/carcass wt), \%: } \\
\hline Total muscle & 0.88 & 0.38 & -0.25 & 0.63 & 0.36 & -0.62 & -0.52 & -0.63 & & -0.92 & -0.82 & -0.49 \\
\hline Total bone & -0.58 & -0.12 & 0.81 & -0.13 & 0.20 & 0.96 & 0.90 & 1.00 & -0.86 & & 0.90 & 0.66 \\
\hline Leg bone & -0.28 & 0.09 & 1.00 & 0.00 & 0.08 & 0.81 & 0.95 & 0.92 & -0.69 & 0.85 & & 0.40 \\
\hline Breast bone & 0.00 & 0.56 & 0.69 & 0.22 & 0.16 & 0.96 & 0.90 & 0.97 & -0.75 & 1.00 & 0.95 & \\
\hline
\end{tabular}


independently of the genes that make a bird breast appears more skeletally developed. Also, if body weight is large due to genotype, birds tend to have greatly long shanks $\left(\mathrm{r}_{\mathrm{G}}=0.90\right)$ associated with reduced $\%$ leg bone in carcass $\left(\mathrm{r}_{\mathrm{G}}=-0.28\right)$. This should be considered whenever explaining eventual leg disorcers in birds selected for increased body weight (LILBURN, 1994).

Whereas the shank length fails to describe the genetic variation in $\%$ total bone $\left(\mathrm{r}_{\mathrm{G}}=\right.$ $-0.04)$ and \%total nuscle $\left(r_{G}=0.17\right)$ in body, the variation in keel length expresses itself largely in these two important characteristics. Also, the variation in keel length expresses itself to much greater extent in carcass weight than is the shank length $\left(\mathrm{r}_{\mathrm{G}}=\right.$ 0.84 vs 0.62 ). These results should emphasize the importance of the keel length in the genetic manipulation of the structural material of the body, precisely, as to avoid any unfavourable reduction in the body skeletal support.

Selection Indexes. The genetic and phenotypic parameters and the relative economic values estimated in the present study were used to construct a full index $\left(\mathrm{I}_{1}\right)$ and other alternatives to limit body bone percentage (BBP) while selecting for increased body weight. The weighing factors, the relative value of each source of information and the accuracy of selection are given in Table 4.

Table 4

Weighing factors (b), percent reduction in rate of overall genetic gain if the trait is dropped (v) and accuracy of selection $\left(\mathrm{r}_{\mathrm{T} 1}\right)$ in index alternatives used to limit reduction in body bone percentage (BBP) while selecting for increased body weight

\begin{tabular}{|c|c|c|c|c|c|c|c|c|c|c|}
\hline \multirow{2}{*}{$\begin{array}{l}\text { Alter- } \\
\text { native }\end{array}$} & \multirow[t]{2}{*}{ Index } & \multicolumn{2}{|c|}{ Body weight } & \multicolumn{2}{|c|}{ Shank length } & \multicolumn{2}{|c|}{ Keel length } & \multicolumn{2}{|c|}{$\begin{array}{c}\text { Dummy } \\
\text { (BBP constant) }\end{array}$} & \multirow[b]{2}{*}{$r_{\mathrm{TI}}$} \\
\hline & & b & v & b & $v$ & b & $v$ & $\mathrm{~b}$ & $\mathrm{v}$ & \\
\hline I & $I_{l}$ & 6.72 & 26.75 & 236.60 & 9.13 & -17.39 & 8.79 & 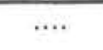 & $\bar{\cdots}$ & 0.95 \\
\hline II & $I_{2}$ & 8.20 & 76.22 & $\cdots$ & $\ldots$. & -15.77 & 9.21 & $\cdots$ & $\cdots$ & 0.86 \\
\hline III & $I_{3}$ & 4.56 & 19.96 & 244.87 & 9.54 & $\cdots$ & $\ldots$. & $\cdots$ & $\cdots$ & 0.86 \\
\hline IV & 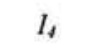 & 6.09 & 100.00 & $\cdots$ & $\cdots$ & $\cdots$ & $\cdots \cdot$ & $\cdots$ & $\cdots$ & 0.78 \\
\hline V & $I_{I(B B P)}$ & 2.99 & 13.65 & 257.48 & 12.63 & 51.62 & 29.88 & -64.23 & -19.30 & 0.79 \\
\hline VI & $I_{2(B B P)}$ & 4.49 & 5.33 & $\cdots$ & $\cdots$ & 60.98 & 5.13 & -63.38 & -12.66 & 0.69 \\
\hline VII & $I_{3(B B P)}$ & -1.12 & 6.76 & 357.80 & 5.13 & $\ldots$. & $\ldots$. & -397.54 & -14.08 & 0.56 \\
\hline
\end{tabular}

Due to its presence in the aggregate genotype, body weight appears to be the most valuable source of information used in the indexes. Its omission would result in a reduction of up to $76 \%$ in the rate of overall genetic gain. When restraining BBP, the relative value of body weight as source of information would decrease dramatically (up to $90 \%$ ). Before and after imposing complete restriction on BBP, keel length seems to be as valuable as shank length when one or both of them are added to body weight (in $I_{1}, I_{2}, I_{3}$ ). However, the relative value of keel length exceeded that of shank length (29.88 vs 12.63) in the restricted full index $\left(\mathrm{I}_{1(\mathrm{BBP})}\right)$.

Weighing factors in restricted indexes, as compared with those in their respective unrestricted forms, showed sharp reduction for body weight $\left(\mathrm{r}_{\mathrm{G}}\right.$ with $\left.\mathrm{BBP}=-0.23\right)$, considerable increases for keel length $\left(\mathrm{r}_{\mathrm{G}}=1.00\right)$ and little change for shank length $\left(\mathrm{r}_{\mathrm{G}}\right.$ 
$=-0.04)$.

The maximum accuracy of selection $\left(\mathrm{r}_{\mathrm{Tl}}=0.95\right)$ was obtained using the full index $\left(\mathrm{I}_{1}\right)$ involving the three sources of information. Selection for an index using information on body weight with either kecl length $\left(\mathrm{I}_{2}\right)$ or shank length $\left(\mathrm{I}_{3}\right)$ should be $91 \%$ as efficient as the full index. Using body weight alone $\left(\mathrm{I}_{4}\right)$ or the restricted full index $\left(\mathrm{I}_{1(\mathrm{BBP})}\right)$ would be $82 \%$ and $83 \%$, respectively, as efficient as selection for $I_{1}$.

Expected response. The effect of the index alternatives were investigated on body weight, BBP and other carcass attributes (Tables 5 and 6).

Table 5

Expected genetic changes in body weight, carcass weight and weights of tissues relative to body weight when using index alternatives to limit reduction in body bone percentage (BBP) while selecting for increased body weight (intensity of selection $=1.00$ )

\begin{tabular}{|c|c|c|c|c|c|c|c|c|}
\hline \multirow[b]{3}{*}{ Alternative } & \multirow[b]{3}{*}{ Index } & \multirow[b]{3}{*}{$\begin{array}{l}\text { Sources of } \\
\text { information* }\end{array}$} & \multirow[b]{3}{*}{ BBP } & \multicolumn{5}{|c|}{ Response } \\
\hline & & & & \multirow[b]{2}{*}{$\begin{array}{l}\text { Body wt } \\
\text { (g) }\end{array}$} & \multirow[b]{2}{*}{$\begin{array}{c}\text { Carcass } \\
\text { wt } \\
\text { (g) }\end{array}$} & \multicolumn{3}{|c|}{100 (component wt/body wt) } \\
\hline & & & & & & $\begin{array}{c}\text { Total } \\
\text { muscle }\end{array}$ & $\begin{array}{l}\text { Leg } \\
\text { bone }\end{array}$ & $\begin{array}{l}\text { Breast } \\
\text { bone }\end{array}$ \\
\hline 1 & $l_{1}$ & BW, BL, SL & -0.73 & 15.9 & 7.2 & 0.54 & -0.16 & -0.04 \\
\hline II & $I_{2}$ & $\mathrm{BW}, \mathrm{BL}$ & -0.72 & 13.1 & 5.9 & 0.67 & -0.18 & -0.09 \\
\hline III & $l_{3}$ & BW, SL & -0.19 & 13.2 & 7.8 & 0.99 & -0.02 & 0.07 \\
\hline IV & $I_{t}$ & BW & -0.22 & 10.8 & 6.5 & 0.30 & -0.01 & 0.02 \\
\hline v & $I_{I(R B P)}$ & $\begin{array}{l}\text { As } I_{l}, \mathrm{BBP} \\
\text { restricted }\end{array}$ & 0.00 & 11.1 & 7.2 & 0.98 & 0.08 & 0.10 \\
\hline VI & $I_{2(R B P)}$ & $\begin{array}{l}\text { As } I_{2}, \mathrm{BBP} \\
\text { restricted }\end{array}$ & 0.00 & 8.5 & 5.9 & 1.10 & 0.05 & 0.05 \\
\hline VII & $I_{3(B B P)}$ & $\begin{array}{l}\text { As } I_{3}, \mathrm{BBP} \\
\text { restricted }\end{array}$ & 0.00 & 5.5 & 3.1 & 0.07 & 0.04 & 0.08 \\
\hline
\end{tabular}

: $\mathrm{BW}=$ body weight. $\mathrm{BL}=$ breast length, $\mathrm{SL}=$ shank length.

Table 5 reveals that alternative II omitting shank length from the full index would still cause almost the same considerable correlated reduction in BBP $(-0.72 \%$ vs $-0.73 \%)$. Deleting keel length from the full index would, however, restrain efficiently the reduction in $\mathrm{BBP}\left(\mathrm{r}_{\mathrm{G}}=-19 \%\right.$ in $\mathrm{I}_{3}$ ) with more favorable changes in the proportion of carcass, total muscle, leg bone and breast bone in the live body. This was not associated with much reduction $(2.7 \mathrm{~g})$ in genetic gain in body weight. Alternative IV dropping both keel length and shank length from the full index would result in similar reduction in BBP but less favorable concomitant changes in carcass characteristics than did alternative III. The recourse to alternative V, implying zero change in BBP while selecting on $I_{1(B B P)}$, would result in much lower increase in body weight despite the favourable outcome obtained in body components. The restricted forms, $\left.I_{2(B B P}\right)$ (alternative VI) and $\mathrm{I}_{3(\mathrm{BBP})}$ ( alternative VII) are of least interest due to their relatively low accuracy and limited improvement in terms of body weight and carcass weight. Table 6 confirms the advantages of alternative III $\left(\mathrm{I}_{3}\right)$ in limiting the reduction of BBP together with reasonable improvement in carcass muscle yield and muscle to bone ratio. 
Table 6

Expected genetic changes in weights of tissues relative to carcass weight when using index alternatives to limit reduction in body bone percentage (BBP) while selecting for increased body weight (intensity of selection = $1.00)$

\begin{tabular}{|c|c|c|c|c|c|c|c|}
\hline \multirow[b]{3}{*}{ Alternative } & \multirow[b]{3}{*}{ Index } & \multirow[b]{3}{*}{$\begin{array}{l}\text { Sources of } \\
\text { iaformation* }\end{array}$} & \multicolumn{5}{|c|}{ Response } \\
\hline & & & \multicolumn{5}{|c|}{100 (component wt/carcass wt) } \\
\hline & & & BBP & $\begin{array}{c}\text { Total } \\
\text { muscle }\end{array}$ & $\begin{array}{l}\text { Total } \\
\text { bone }\end{array}$ & $\begin{array}{c}\text { Leg } \\
\text { bone }\end{array}$ & $\begin{array}{c}\text { Breast } \\
\text { bone }\end{array}$ \\
\hline 1 & $I_{t}$ & BW, BL, SL. & -0.73 & 1.68 & -1.40 & -0.32 & 0.01 \\
\hline II & $I_{2}$ & $\mathrm{BW}, \mathrm{BL}$ & -0.72 & 1.67 & -1.46 & -0.37 & -0.10 \\
\hline III & $l_{3}$ & BW, SL & -0.19 & 1.10 & -0.64 & -0.07 & 0.11 \\
\hline IV & l. & BW & -0.22 & 1.14 & -0.74 & -0.13 & 0.00 \\
\hline $\mathrm{V}$ & $I_{I(B B I)}$ & $\begin{array}{l}\text { As } I_{l}, \mathrm{BBP} \\
\text { restricted }\end{array}$ & 0.00 & 0.77 & -0.30 & 0.03 & 0.15 \\
\hline VI & $I_{2(B B I)}$ & $\begin{array}{l}\text { As } l_{2}, \text { BBP } \\
\text { restricted }\end{array}$ & 0.00 & 0.78 & -0.60 & -0.02 & 0.04 \\
\hline VII & $I_{3(B B I)}$ & $\begin{array}{l}\text { As } I_{3}, \mathrm{BBP} \\
\text { restricted }\end{array}$ & 0.00 & 0.16 & 0.02 & 0.06 & 0.16 \\
\hline
\end{tabular}

The results discussed in this paper shows that use of body weight and shank length as sources of information in a selection index would raise the interesting possibility of satisfying needs of produccrs (increased body weight with minimum reduction in leg bone) and consumers (greater carcass weight with advantageous muscle to bone ratio).

\section{References}

\section{ABDELATIF, M.A.:}

Genetic study on Dandarawy chickens. II. Heritability of live and carcass measurements. Genetique, Selection, Evolution, 21 (1989), 199-203

ABDEL-GAWAD, E.M.; EL-IBIARY, H.M.:

Heritability estimates of productive traits in the Fayoumi, Leghorn and Rhode Island Red chickens. 1. Body weight, shank length, rate of feathering and chick viability. Agricultural Research Review, Cairo, 49 (1971), 69-77

AHUJA, S.D.; DUTTA, O.P.; AGARWAL, S.K.; KATARIA, M.C.:

Genetic parameter estimates of slaughter traits in Japanese quail. Estimates on observed traits. Avian Research, 67 (1983), 9-12

BACON, W.L.; NESTOR, K.E.; RENNER, P.A.:

The influence of genetic increases in body weight and shank width on the abdominal fat pad and carcass composition of turkeys. Poultry Science 65 (1986), 391-397

CUNNINGHAM, E.P.; MOEN, R.A.; GJEDREM, T.:

Restriction of selection indexes. Biometrics 26 (1970), 67-74

DARTON, R.A.:

Rotation in factor analysis. The Statistician, 29 (1980), 167-194

DUBOVIK, G.V.:

Heritability and genetic and phenotypic correlations of live weight with some external characters in

EL-FIKY, F.A.: hens of the Hybro line cross. (In Russian) Animal Breeding Abstracts (1972), 40 (1970), 4373

Genetic studies on some economic traits in Japanese quail. Ph.D. Thesis, Al-Azhar University, Cairo, Egypt. 1991

HARVEY, W.R.:

LSMLMW Mixed Least Squares and Maximum Likelihood Computer Program PC-2 Version. Dairy Science Dept. The OH State Univ., Columbus, OH. 1990 
HASSAN, M.F.; KOSBA, M.A.; SOLIMAN, F.N.K.; BAHIE EL-DEEN, M: Correlated response in body weight to selection for dressing percentage in Japanese quail. Egyptian Poultry Science, 12 (1992), 535-553

KAWAHARA, T.; SAITO, K.:

Genetic parameters of organ and body weights in the Japanese quail. Poultry Science, 55 (1976), 12471252

KOSBA, M.A.; HASSAN, M.F.; SOLIMAN, M.A.; AZIZ, M.A.; BAHIE EL-DEEN, M.: Selection for dressing percentage in Japanese quail. Egyptian Poultry Science, 12 (1992), 333-346

KRUEGER, W.F.; ATKINSON, R.L.; QUISENBERRY, J.H.; BRADLEY, J.W.: Heritability of body weight and conformation traits and their genetic association in turkeys. Poultry LILBURN, M.S.: Skeletal growth of commercial poultry species. Poultry Science, 73 (1994), 897-903

MERCER, J.T.; HILL, W.G.: Estimation of genetic parameters for skeletal defects in broiler chickens. Heredity, 53 (1984), 193-203

NESTOR, K.E.; BACON, W.L.; MOORHEAD, P.D.; SAIF, Y.M.; HAVENSTEIN, G.B.; RENNER, P.A.; Comparison of bone and muscle growth in turkey lines selected for increased body weight and increased shank width. Poultry Science, 66 (1987), 1421-1428

PINGEL, H.; BOCK, M.; SCHWEITZER, W.; MERTENS H.:

Untersuchungen uber die Mast- und Schlachtleistung von Pekingenten und die Möglichkeiten zur Erhőhung ihres Brustfleischansatzes. Arch. Geflugelz. Kleintierk., 18 (1969), 151-168

SATO, K.; KISHI, H.; INO, T.:

Genetic parameters of live weight, evisccrated weight, organ weights and muscle weights in Japanese quail males. Scientific Reports of the Faculty of Agriculture, Okayama University No. 59 (1982), 3948. (In Japanese) Animal Breeding Abstracts 51 (1983), 4661

SATO, K.; MATSUMURA, T.; KAWAMOTO, Y.; INO, T.:

Genetic parameters of body weight, muscle weights and skeleton characteristics in Japanese quail males. Scientific Reports of the Faculty of Agriculture, Okayama University No. 66 (1985), 31-40. (In Japanese) Animal Breeding Abstracts 54 (1986), 6241

SHAHIN, K.A.; ABDALLAH, O.Y.; SHEMEIS, A.R.:

Genetic influences on growth and partition of fat between depots and its distribution in fowl carcasses. Reproduction Nutrition Development, 30 (1990), 673-681

SHARAF, M.M.:

Genetic and nongenetic estimates of some reproductive and productive traits in Japanese quails. Egyptian Poultry Science, 12 (1992), 211-231

SOLIMAN, F.N.K.:

Genetic parameters for carcass traits of Japanese quail at 56 days of age. Egyptian Poultry Science, 12 (1992), 233-247

Received: 1999-05-31

Accepted: 2000-09-01

Authors' addresses

Prof. Dr. KARIMA A. SHAHIN, Dr. AHMED R. SHEMEIS, Prof. Dr. OMAR Y. ABDALLA

Department of Animal Production, Faculty of Agriculture,

Ain Shams University,

Shoubra Al-kheima,

11241 Cairo, Egypt

Prof.Dr. KAMAL SALEH

Tanta University, Egypt 
Arch. Tierz., Dummerstorf.43 (2000) 5, 544

\title{
Buchbesprechung
}

\section{Pferderassen der Welt}

\author{
WOLFGANG KRESSE
}

368 Seiten, 280 Farbfotos, 12 Zeichnungen, Verlag Eugen Ulmer, Stuttgart, 1999, ISBN 3-8001-7392-1, 49,80 DM, 364,00 öS, 46,00sFr

In einer Zeit zunehmender Technisierung und elektronischer Medien in allen Arbeits- und Lebensbereichen erhălt die Beziehung vieler Menschen zu Haustieren einen immer größeren Stellenwert. Das gilt in besonderer Weise für das Pferd. Durch das vorliegende Buch ist der Verlag einmal mehr diesem Bedürfnis in gelungener Weise nachgekommen. Dieses Buch zeichnet ein Gesamtbild der faszinierenden Vielfalt vorhandener Pferderassen. In der gelungenen Kombination von Wort und Bild vermittelt es Wissenswertes uber mehr als 300 Rassen. Es ist nicht einfach die Pferde- und Ponyrassen, so sie denn über ein Stutbuch verfügen und Pferdetypen, die nach ihrem Nutzungszweck definiert werden, zu klassifizieren. Das war auch nicht das Ziel des Autors, dem es darum ging dem Leser in gebotener Kürze einen umfassenden Überblick Uber ca. 320 Pferde- und Ponyrassen der Welt zu geben und sie in diesem Bilderatlas in alphabetischer Reihenfolge aufzufuhren. Dass es ihm dabei gelang dieses Weltrassenspektrum, neben den wichtigsten Angaben zu Exterieur, Verbreitung, Leistungsmerkmalen, Verwendung und Zuchtgeschichte, meist auch durch farbige Abbildungen vorzustellen, ist ein besonderes Verdienst. Es macht dieses Buch daher auch für Leser interessant, die Freude an schönen Tierbildern haben und nicht direkt mit der Pferdehaltung liiert sind.

In den ersten einführenden, allgemeinen Buchabschnitten werden Ursprung des Pferdes, das Pferd in vorgeschichtlicher Zeit, das frühgeschichtliche Pferd und die Entwicklung der Rassen vorgestellt. Informationen Uber „Das Pferd macht Weltgeschichte" und „Das Pferd in der Kulturgeschichte" beschließen diesen mit einer Fulle von Informationen zusammengestellten Buchteil. Sie belegen, dass im Vergleich zu den meisten anderen Haustieren, das relativ spät domestizierte Pferd die Menschen bis in die Gegenwart in unterschiedlicher Weise auf allen ihren Wegen begleitet hat und ihnen ein zuverlässiger Partner geworden ist. Im Hauptteil des Buches werden die Rassen vorgestellt. Der Leser findet fur jede Rasse in komplexer, ubersichtlicher und fundierter Weise, sich auf das Wesentliche beschränkende Informationen. Die Textaussagen werden durch ausdrucksvolle Farbfotos unterstützt. Ergänzt wird dieser farbige Bildatlas durch ein umfangreiches internationales Adressenverzeichnis sowie eine Literaturubersicht.

Dieses Buch hält nicht nur für Pferdezüchter, -freunde und -liebhaber eine Fülle von sorgfältig zusammengetragenen Informationen bereit. Es verschafft einen umfassenden Überblick Uber die bemerkenswerte Vielfalt des Weltrassenspektrums. Als unverzichtbares Nachschlagewerk für jeden ambitionierten Pferdefreund ist es uneingeschrănkt Tierliebhabern und vielen weiteren interessierten Lesern zu empfehlen. 